\title{
Psychological Study of the Persons Suffering From Sickle Cell Disease in Raigarh District of Chhattisgarh State
}

\author{
Dr. Rajesh Kumar Ajagallay ${ }^{1}$, Dr. Gaukaran Janghel ${ }^{2}$, Dr. Vimal Chandra \\ Bhagat $^{3}$, Viyata Chanda ${ }^{4}$, Dr. Rakesh Kumar Agrawal ${ }^{5}$, Dr. Neelam Naik ${ }^{6}$
}

\section{ABSTRACT}

Background: Sickle cell disease is an inherited blood disorder in which the body produces abnormal shaped red blood cells (RBC). The disease affects both biological and psychosocial aspects of patients. Aim: Present study aimed at investigating the different mental health dimensions used by heterozygous and homozygous sickle cell anemic patients. Method: The cross-sectional study design with the total 100 sickle cell anemic adolescents of both the sexes were selected in 10 to 20 year age groups, from various hospitals and health clinics of Chhattisgarh, India. The correlation analysis was used for analyzing the data. Results: Total 100 patients were selected which consisted of 30 homozygous and 70 heterozygous adolescent patients with sickle cell gene. The Emotional Stability was which higher significantly correlated with the intelligence quotients, IQ $(r=.387, \mathrm{p}<.001)$ than the other dimensions. Only two dimensions of mental health viz. emotional stability $(\mathrm{t}-2.38 ; \mathrm{p}<.018)$ and self-concept $(\mathrm{t}-2.32$; $\mathrm{p}<.001)$ of sickle cell patients which differed among heterozygous and homozygous patients.

\section{Keywords: Sickle Cell Disease, Mental Health Dimensions}

Sickle cell disease is an inherited blood disorder in which the bone marrow produces abnormal shaped red blood cells. These cells become stiff and C-shaped and the hemoglobin clumps together. These sickle cells block blood and oxygen flow in blood vessels and these cells break down more rapidly than normal red blood cells, which results in severe anaemia.

\footnotetext{
${ }^{1}$ MD. Psychiatry, Associate Professor, Lakhiram Agrawal Memorial Govt. Medical College, Raigarh, CG, India

${ }^{2}$ Ph. D Psychology, Clinical psychologist, Lakhiram Agrawal Memorial Govt. Medical College, Raigarh, CG, India

${ }^{3}$ MD Psychiatry (Assistant Professor, Lakhiram Agrawal Memorial Govt. Medical College, Raigarh, CG, India

${ }^{4}$ M. Phil Psychology, Clinical Psychologist, Lakhiram Agrawal Memorial Govt. Medical College, Raigarh, CG, India

${ }^{5}$ MBBS, Lakhiram Agrawal Memorial Govt. Medical College, Raigarh, CG, India

${ }^{6}$ MBBS, Lakhiram Agrawal Memorial Govt. Medical College, Raigarh, CG, India

*Responding Author
}

Received: January 25, 2017; Revision Received: February 16, 2017; Accepted: February 24, 2017 (C) 2017 Ajagallay R, Janghel G, Bhagat V, Chanda V, Agrawal R, Naik N; licensee IJIP. This is an Open Access Research distributed under the terms of the Creative Commons Attribution License (www.creativecommons.org/licenses/by/2.0), which permits unrestricted use, distribution, and reproduction in any Medium, provided the original work is properly cited. 


\section{Psychological Study of the Persons Suffering From Sickle Cell Disease in Raigarh District of Chhattisgarh State}

Sickle cell disease (SCD) is the most common genetic hemoglobin disorder, affecting more than 70,000 Americans, primarily those of African and Mediterranean origins. The disease is characterized by chronic hemolytic anaemia, vaso-occlusive complications, and increased risk of infection with associated shortened lifespan up to 30 years (Plott, et al.1994).

The mental imbalance is one of the most important problems for persons with sickle cell disease which may be due to continued panic condition. The sickle cell disease is an autosomal recessive genetic disorder and also the most common hemoglobinopathy. The homozygous sickle cell anemia, HbSS is a more severe form of sickle cell disease than sickle cell trait, HbAS (Levenson, et al. 2008). Sickle cell disease shows in two major forms: sickle cell beta thalassemia ( $\mathrm{S} \beta 0$ and $\mathrm{S} \beta+$ ) and sickle cell hemoglobin- C (SC) (Levenson, et al. 2008).

Kornhauser defined the mental health in 1965 as "those behaviors, perceptions, and feelings which determine the overall level of personal effectiveness, success, happiness, and excellence of functioning as a person". The concept of mental health takes a "Gestalt" view of the individual with which it incorporates the overall personality characteristics and behavior of the individual (Sing \& Sengupta, 1983). A homogeneous organization of desirable attitudes, healthy values and right self-concept, a scientific perception of the world were shown by a mentally healthy person (Erickson, 1993; Hurlock, 1972). Morgan and Jackson, 1986 conducted a study and found that adolescents with sickle cell anemia reported less satisfaction with their bodies, more symptoms of depression and spend less time in social and unsocial activities (Morgan \& Jackson, 1998). Earlier studies have been done with an aim to determine the prevalence of psychiatric disorders among sickle cell adolescents and it was observed that a high prevalence of psychiatric disorders including depression, anxiety, attention-deficit/ hyperactivity disorder, oppositional defiant disorder, and conduct disorder (Benton, Boyd, Ifeagwu \& Smith-Whifley, 2011).

Witmer \& Sweeny, 1992; Hattie, Myers \& Sweeny (2004), stated that a mental well-being and mental health are holistic concepts consisting of anthropological, sociological, educational, psychological and religious perspectives as well as theoretical perspectives from personality, social, clinical, health and developmental psychology. The present study evaluates mental health by six dimensions viz. Emotional Stability, Overall Adjustment, Autonomy, Security-Insecurity, Self-Concept and Intelligence of patients with sickle cell disease and their relationship to each other.

\section{Objectives of the research-}

1. To explore the mental health of Heterozygous and homozygous sickle cell anemic patients. 


\section{Psychological Study of the Persons Suffering From Sickle Cell Disease in Raigarh District of Chhattisgarh State}

\section{Research design}

The cross-sectional study design and purposive sampling technique was used in the current research.

\section{METHODOLOGY}

\section{Inclusion criteria for participants}

Those persons who were already medically diagnosed with sickle cell anemia by sickle cell unit and pathology in LAMGMC, Raigarh, India and who gave consent were included in the study.

\section{Target group}

The target group of the present study was person suffering from sickle cell anemia in Raigarh district of Chhattisgarh state.

\section{Size of sample}

Total 100 adolescents with sickle cell anemia of both sexes were selected purposively from 10 to 20 year of age group, from LAMGMC, Raigarh, Chhattisgarh, India. These participants were clinically diagnosed as homozygous and heterozygous sickle cell anemia by sickle cell unit and pathological laboratory.

\section{Measures}

\section{Mental Health Battery (MHB- Singh \& Sengupta, 1983)}

The Mental Health Battery (MHB), basically developed by Sing \& Sengupta (1983) was opted for the present investigation. The mental health battery was using for measurement of mental health dimension in sickle cell anemic persons. The MHB measure used six popular mental health dimensions of a person, viz. Emotional Stability (ES), Overall Adjustment (OA), Autonomy (AU), Security-Insecurity (SI), Self-Concept (SC) and Intelligence (IQ). The MHB is a reliable and valid instrument for the measurement of mental health. Reliability of the present data showed that the coefficient of Alpha $(\alpha)$ is 0.88 .

\section{Statistical analysis}

The Obtained data was analyzed in the Pearson correlation analysis for the correlation of mental health dimension in homozygous and heterozygous sickle cell patients and t- test was applied for statistically significant differences between mental health dimension of Heterozygous and Homozygous patients.

\section{RESULT}

Total 100 patients were selected out of which of 30 were homozygous and 70 were heterozygous adolescent patients with sickle cell gene. 


\section{Psychological Study of the Persons Suffering From Sickle Cell Disease in Raigarh District of Chhattisgarh State}

The table no. 1 shows a correlation between different mental health dimensions in heterozygous sickle cell patients. It revealed that each dimension of mental health of heterozygous sickle cell patients highly correlated with other dimensions, as Emotional Stability was higher significantly correlated with the intelligence quotients, IQ $(\mathrm{r}=.387, \mathrm{p}<.001)$ than the other dimensions, whereas Overall Adjustment was also positively correlated with the Self-concept $(r=.447, \mathrm{p}<$ $.001)$, Autonomy was positively and highly correlated with Self-concept, SC $(r=.345, p<.001)$ than the other dimensions, Security-insecurity also highly correlated with the self-concept $(\mathrm{r}=$ $.433, \mathrm{p}<.001)$ as compared to other dimensions.

Table 1 shows the correlation of mental health dimension in heterozygous sickle cell patients

\begin{tabular}{|c|c|c|c|c|c|c|}
\hline Correlation ES & $\mathbf{O A}$ & AY & SI & SC & IQ & MHB TOTAL \\
\hline 1.000 & $.299 * *$ & NS & $.245^{* *}$ & $.313 * *$ & $.387 * *$ & $.644 * *$ \\
\hline OA & 1.000 & $.386 * *$ & $.377 * *$ & $.447 * *$ & $.264 * *$ & $.739 * *$ \\
\hline $\mathrm{AY}$ & & 1.000 & $.254^{* *}$ & $.345 * *$ & $.188^{*}$ & $.510 * *$ \\
\hline SI & & & 1.000 & $.433 * *$ & NS & $.563 * *$ \\
\hline SC & & & & 1.000 & $.194 *$ & $.634 * *$ \\
\hline IQ & & & & & 1.000 & $.690 * *$ \\
\hline MHB Total & & & & & & 1.000 \\
\hline
\end{tabular}

$*(\mathrm{p}<0.05) \quad * *(\mathrm{p}<0.01)$

The table no. 2 shows a correlation between dimensions of mental health among homozygous sickle cell patients. The table revealed that emotional stability (ES) was strongly correlated with the overall adjustment $(\mathrm{OA})(\mathrm{r}=.697, \mathrm{p}<.001)$, than the other dimensions, whereas overall adjustment, OA was highly correlated with dimension IQ $(\mathrm{r}=.721, \mathrm{p}<.001)$, than the other dimension, Autonomy(AY) was significantly correlated with the intelligence quotient(IQ)( $r$ $=.483, \mathrm{p}<.001$ ), than other dimensions. security insecurity (SI) was highly and positively correlated with Emotional stability (ES) $(\mathrm{r}=.298$, p.001) while other dimension of mental health were not correlated with each other.

Table 2 showing the correlation of mental health dimension in homozygous patients

\begin{tabular}{lcclcccc}
\hline Correlation & ES & OA & AY & SI & SC & IQ & MHB TOTAL \\
\hline ES & 1.000 & $.697^{* *}$ & NS & $.298^{* *}$ & $.478^{* *}$ & $.670^{* *}$ & $.865^{* *}$ \\
OA & & 1.000 & $.465^{* *}$ & NS & NS & $.721^{* *}$ & $.868^{* *}$ \\
AY & & & 1.000 & NS & NS & $.483^{* *}$ & $.495^{* *}$ \\
SI & & & & 1.000 & NS & NS & NS \\
SC & & & & & 1.000 & $.355^{*}$ & $.437^{*}$ \\
IQ & & & & & & 1.000 & $.904^{* *}$ \\
MHB Total & & & & & & 1.000
\end{tabular}

$*(\mathrm{p}<0.05) \quad * *(\mathrm{p}<0.01)$

(C) The International Journal of Indian Psychology, ISSN 2348-5396 (e)| ISSN: 2349-3429 (p) | 36 


\section{Psychological Study of the Persons Suffering From Sickle Cell Disease in Raigarh District of Chhattisgarh State}

The table no. 3 shows mean, standard deviation, t-value, and two-tailed significance of heterozygous and homozygous patients with sickle cell gene. It revealed only two dimensions of mental health viz. emotional stability (t- 2.38; $\mathrm{p}<.018$ ) and self concept (t- 3.32; $\mathrm{p}<.001)$ of sickle cell patients which differed among heterozygous and homozygous patients. The mean and SD value shows total mental health $(75.4 \pm 12.18)$ with Emotional Stability, Self Concept, Autonomy, Security insecurity, Overall Adjustment of heterozygous patients to be higher than total mental health score(71.80 \pm 15.26$)$ of homozygous patients.

Table 3 showing the differences between mental health dimension of Heterozygous and Homozygous patients

\begin{tabular}{|c|c|c|c|c|c|c|}
\hline SN & Mental Health dimensions & Zygosity & Mean & SD & t- Value & Significant \\
\hline \multirow[t]{2}{*}{1} & \multirow[b]{2}{*}{ Emotional Stability } & Heterozygous & 9.79 & 3.28 & 2.38 & .018 \\
\hline & & Homozygous & 8.43 & 3.25 & 2.39 & .019 \\
\hline \multirow[t]{2}{*}{2} & \multirow[b]{2}{*}{ Overall Adjustment } & Heterozygous & 24.54 & 4.15 & 0.76 & .450 \\
\hline & & Homozygous & 23.93 & 5.60 & 0.67 & .507 \\
\hline \multirow[t]{2}{*}{3} & \multirow[b]{2}{*}{ Autonomy } & Heterozygous & 10.84 & 2.01 & 1.33 & .184 \\
\hline & & Homozygous & 10.37 & 2.00 & 1.34 & .185 \\
\hline \multirow[t]{2}{*}{4} & \multirow[b]{2}{*}{ Security insecurity } & Heterozygous & 9.58 & 2.10 & 1.62 & .106 \\
\hline & & Homozygous & 8.98 & 2.17 & 1.60 & .113 \\
\hline \multirow[t]{2}{*}{5} & \multirow[b]{2}{*}{ Self Concept } & Heterozygous & 7.31 & 2.30 & 3.32 & .001 \\
\hline & & Homozygous & 6.02 & 2.04 & 3.50 & .001 \\
\hline \multirow[t]{2}{*}{6} & \multirow[b]{2}{*}{ Intelligence } & Heterozygous & 13.38 & 4.83 & -0.76 & .446 \\
\hline & & Homozygous & 14.07 & 5.89 & -0.70 & .485 \\
\hline \multirow[t]{2}{*}{7} & \multirow[b]{2}{*}{ Total Mental Health Score } & Heterozygous & 75.44 & 12.18 & 1.59 & .114 \\
\hline & & Homozygous & 71.80 & 15.26 & 1.44 & .153 \\
\hline
\end{tabular}

\section{DISCUSSION}

The severity of Sickle cell disease is affected by hereditary and some environmental factors viz. mental health, socio-demographic etc. The present study aims to find out those factors which influence the mental status and physical condition of heterozygous and homozygous patients. Some studies have suggested that the sickle cell disease affected persons use different strategies for coping with the problems of sickling. Seigel, Golden, Gough (1990) assessed the association between depression, self-esteem, and life events in adolescents with asthma, sickle cell disease, and diabetes.

Schatz \& Roberts (2005) examine that the short term memory span and working memory performance among the children with SCD $(n=25)$ and demographically matched comparison children $(n=25)$, and it was observed that the children with SCD had difficulties only for digit span- backward performance. Schatz, et al. (2002) identified auditory verbal measures, and which found the areas of deficit in Wechsler scale vocabulary, arithmetic digit span, subtest were significant in SCD. Similarly the numbers of studies have identified impairments in cognitive

(C) The International Journal of Indian Psychology, ISSN 2348-5396 (e)| ISSN: 2349-3429 (p) | 37 


\section{Psychological Study of the Persons Suffering From Sickle Cell Disease in Raigarh District of Chhattisgarh State}

function in children with SCD. Cognitive deficits have been noted in general intelligence ( Knight, Singhal Thomas, et al. 1995; Wasserman, Wiliams \& Fairclough, et al. 1991), academic abilities such as reading (Wasserman, Wiliams \& Fairclough, et al. 1991; Fowler, Whitt, \& Lallinger, et al. 1988), writing, arithmetic (Wasserman, Wiliams \& Fairclough, et al. 1991), spelling (Fowler, Whitt, \& Lallinger, et al. 1988), attention (Sano, Haggerty \& Kugler, et al. 1996), Visio spatial (Wasserman, Wiliams \& Fairclough, et al. 1991; Sano, Haggerty \& Kugler, et al. 1996), and memory (Wasserman, Wiliams \& Fairclough, et al. 1991), general intelligence (Armstrong, Thompson \& Wang, et al.1996; Hairman, Griffith \& Hurtige, et al. 1991), and academic abilities such as arithmetic and language (Armstrong, Thompson \& Wang, et al.1996). Bennett (1994) showed that children with SCD were at increased risk factor for depressive symptoms.

Number of studies has been conducted to specifically examine the behavior problem of children and adolescent with SCD, and the finding have indicated an increased frequency of behavioural or psychological problems (Whitte \& Debaum, 1998).

They examined 80 adolescents with age range of 12 to 18 years and compared to a group of 100 demographically matched peers. Both groups completed the BDI, Rosenberg Scale of SelfEsteem, and the McCutcheon Life Events Checklist. They found that the mean depression scores were significantly higher in the chronic disease groups compared to healthy peers and the illness groups were more likely to have low self-esteem. However similar study no differences were found illness groups in depression, self-esteem or life events (Seigal, Golden, Gough, Lashley, \& Sacher, 1990). Few other studies revealed that the most frequent psychological problems encountered were anxiety, depression, social withdrawal, aggression, poor relationships and school performance (Evans, Burlew \& Ofer, 1988; Brown, Armstrong \& Eckman, 1993). Some case reports also indicated high levels of parental anxiety, overprotection, guilt and excessive feelings of responsibility (Graham, Reed, Levit, Fine \& Medalie, 1982; Whitten \& Fischoff, 1974).

Noll et al. (1996) found that males with sickle cell disease are less aggressive whereas females with SCD are less sociable and less well-adjusted than the peer groups. The common complications of sickle cell disease including chronic fatigue and small physical size, chronic pain and stigma related to illness may explain these behaviors. There are also significant problems in adjustment particularly for adolescents with sickle cell disease, and most significantly in the areas of behavior and social adjustment ( Hurtig et al. 1986). Seigel, Golden, Gough (1990) found that the mean depression scores were significantly higher in the illness group and more likely to have low self-esteem compared to healthy peers. They concluded that the most frequent psychological problems encountered are anxiety, depression, social withdrawal, aggression, poor relationships and poor scholastic performance. Both children and 


\section{Psychological Study of the Persons Suffering From Sickle Cell Disease in Raigarh District of Chhattisgarh State}

adults with Sickle cell disease suffer from neurocognitive impairments and psychological complications including inappropriate pain coping strategies; reduced quality of life owing to restrictions in daily functioning, anxiety, and depression (Anie, 2005).

Sickle cell disease has significant negative influences on IQ and cognitive functions. Consistent with these findings, our study revealed that two dimensions of mental health viz. emotional stability and self concept of sickle cell patients were significantly higher among heterozygous compared to homozygous patients. The total mental health with Emotional Stability, SelfConcept, Autonomy, Security insecurity, and Overall Adjustment of heterozygous patients are higher as compare to homozygous patients and could be attributed to Homozygous Sickle cell disease patients having more somatic problems compared to heterozygous and there is a significant positive relationship between Maladaptive coping style and somatic problems (Ogre, et al. 2016).

The mean values of IQ in sickle cell disease were 5.6 points lower than in normal healthy controls. The difference occurred in both verbal and performance subscales of the IQ score (Knight et al. 1995).

\section{CONCLUSION}

There are limitations to this study. We used a cross-sectional study design, and thus, causal interpretations of the results cannot be established. It is possible that patients with more severe cases of Sickle cell disease would go to a higher center and thus, may be more informed about their disease. We have not included the normal healthy control in our /study; therefore we cannot compare it with the general population. Future research comparing mental health and attitudes toward sickle cell disease in other regions of Chhattisgarh would be beneficial to detect mental health problems and stigma related to illness which is most neglected part of this illness.

\section{Acknowledgement}

I would like to thank all the patients of sickle cell disease registered in the Late. Shree Lakhi Ram Agrawal Memorial Medical College (LAMGMC) Raigarh, Chhattisgarh, India.

Conflict of Interest: The author(s) declare that they have no conflict of interests.

\section{REFERENCES}

Anie, K. A. (2005). Psychological complications in sickle cell disease. British journal of haematology, 129(6), 723-729.

Armstrong, F. D., Lemanek, K. L., Pegelow, C. H., Gonzalez, J. C., \& Martinez, A. (1993). Impact of lifestyle disruption on parent and child coping, knowledge, and parental discipline in children with sickle cell anaemia. Children's Health Care, 22: 189-203. 


\section{Psychological Study of the Persons Suffering From Sickle Cell Disease in Raigarh District of Chhattisgarh State}

Armstrong, F. D., Thompson, R. J., Wong, W. et al. (1996). Cognitive function and brain imaging in children with sickle cell disease. Journal of pediatric, 97, 864-70.

Bennett, D. S. (1994). Depression among children with chronic medical problems: A metaanalysis. Journal of Pediatric Psychology, 19, 149-69.

Benton, T. D., Boyd, R., Ifeagwu, J., Feldtmose, E. \& Smith-Whitley, K. (2011). Psychiatric Diagnosis in Adolescents with sickle cell Disease: A Preliminary Report. Current Psychiatric Report, 13: 111-115.

Brown, R. T., Armstrong, F. D. \& Eckman, J. R. (1993). Neurocognitive aspects of sickle cell disease. Journal of Learning Disabilities, 26: 33-45.

Erickson, E. (1993). Childhood and Society (2nd ed.): New York, Norton; 1993.

Evans, R. C., Burlew, A. K., Oler, C. H. (1988). Children with sickle cell anaemia: parental relations, parent-child relations, and child behavior. Social Work, 33: 127-130.

Fowler, M. G., Whitt, J. K., Lollinger, R. R. et al. (1988). Neuropsychological and academic functioning of children with sickle cell anemia. Journal of Developmental and Behavioral Pediatrics, 9, 213-20.

Graham, A. V., Reed, K. G., Levit, C., Fine, M., \& Medalie, J. H. (1982). Care of a troubled family and their child with sickle cell anaemia. Journal of Family Practice, 15: 23-32.

Hairman, L. M. F., Griffith, E. R., Hurtige, A. L., et al. (1991). Functional out comes of children with sickle cell disease affected by stroke. Arch. Phys. Med. Rehabilitation, 72, 498-502.

Hattie, J. A., Myers, J. E. \& Sweeney, T. J. (2004). A factor structure of wellness: Theory, assessment, analysis and practice. Journal of Counseling and Development, 82 (3): 354-364.

Hurlock, E. B. (1972). Child development: New York, McGraw-Hill.

Hurtig, A. L., \& White, L. S. (1986). Psychosocial adjustment in children and adolescents with sickle cell disease. Journal of Pediatric Psychology, 11(3), 411-427.

Jahoda, M. (1956). Current concepts of positive mental health: New York: Basic Books, Inc; 1956.

Knight, S., Singhal, A., Thomas, P. et al. (1995). Factors associated with lowered intelligence in homozygous sickle cell disease. Arch. Dis. Child, 73, 316-20.

Knight, S., Singhal, A., Thomas, P., \& Serjeant, G. (1995). Factors associated with lowered intelligence in homozygous sickle cell disease. Archives of disease in childhood, 73(4), 316-320.

Levenson, J. L., McClish, D. K., Dahman, B. A., Bovbjerg, V. E., De A. Citero, V. \& Penberthy, L. T., et al. (2008). Depression and anxiety in adults with sickle cell disease: The PiSCES project. Psychosomatic Medicine, 70 (2): 192-196.

Morgan, S. A. \& Jackson, J. (1986). Psychological and social concomitants of sickle cell anemia in Adolescents. Journal of Pediatric Psychology, 11 (3): 429-440.

Noll, R. B., Vannatta, K., Koontz, K., Kalinyak, K., Bukowski, W. M., \& Davies, W. (1996). Peer relationships and emotional well-being of youngsters with sickle cell disease. Child development, 67(2), 423-436. 


\section{Psychological Study of the Persons Suffering From Sickle Cell Disease in Raigarh District of Chhattisgarh State}

Ogre, S. C., Chakravarty, M., Shrivastava, P., \& Janghel, G. (2016). Relationship between somatic problems and their coping strategies among sickle cell anaemic adolescents. Indian Journal of Health and Wellbeing, 7(5), 510.

Platt, O. S., Brambilla, D. J., Rosse, W. F., Milner, P. F., Castro, O., Steinberg, M. H. \& Klug, P. P. (1994). Mortality in sickle cell disease: Life expectancy and risk factors for early death. N. England Journal of Medicine, 330: 1639- 1644.

Sano, M., Haggerty, R., Kugler, S. et al. (1996). Neuropsychiatric Neuropsychology Behavioral Neurology, 9, 242-247.

Schatz, J. \& Roberts, C. W. (2005). Short term memory in children with sickle cell disease: Executive versus modality-specific processing deficits. Archives of Clinical Neuropsychology, 20, 1073-1085. Doi. 10.1016/J.com.2005.06.008.

Schatz, J., Fink, R. L., Kellett, J. M. \& Kramer, J. H. (2002). Cognitive functioning in children with sickle cell disease: A meta-analysis. Journal of Pediatric Psychology, 8, 739-748.

Seigel, W. M., Golden, N. H., Gough, J. W., Lashley, M. S. \& Sacker, I. M. (1990). Depression, self-esteem, and life events in adolescents with chronic diseases. Journal of Adolescence Health Care, 11: 501- 504.

Singh, A. K. \& Sengupta, A. (1983). Manual for mental health battery. Purchased by Ankur Psychological Agency Indira Nagar, Lakhnow; 1983.

Swift, A. V., Cohen, M. J., Hynd, G. W. et al. (1989). Neuropsychological impairment in children with sickle cell anemia. Journal of Pediatrics, 84, 1077-85.

Treiber, F. A., Mabe, P. A., \& Wilson, G. (1987). Psychological adjustment of sickle cell children and their siblings. Children's Health Care, 16: 82-84.

Wasserman, A. L., Wiliamas, J. A., Fairclough, D. L. et al. (1991). Subtle neuropsychological deficits in children with sickle cell disease. American Journal of Pediatrics Hematology Oncology, 13, 14-20.

Whitten, C. F., Fischoff, J. (1974). Psychosocial effects of sickle cell disease. Archives of Internal Medicine, 133: 681-689.

Witmer, J. M. \& Sweeny, T. J. (1992). A holistic model for wellness and prevention over the life span. Journal of Counseling and Development, 71 (2): 140-148.

How to cite this article: Ajagallay R, Janghel G, Bhagat V, Chanda V, Agrawal R, Naik N (2017), Psychological Study of the Persons Suffering From Sickle Cell Disease in Raigarh District of Chhattisgarh State, International Journal of Indian Psychology, Volume 4, Issue 2, No. 92, ISSN:2348-5396 (e), ISSN:2349-3429 (p), DIP:18.01.104/20170402, ISBN:978-1-36578192-6 